\title{
Paths to Rehabilitation? The Possibilities of Treatment
}

As previous chapters have established, heads and faces might be deliberately targeted in cases of injury; marking of the head and face formed part and parcel of many legal sanctions against thieves, traitors and sexually transgressive men and women, but almost all early medieval lawcodes penalized similar interpersonal violence. Facial and head wounds opened a person to stigma and ridicule, and honor was bound up in facial appearance, women's faces were a site of particular meaning, and episodes of mutilation and disfigurement were sometimes written up as if staring at the process and its aftermath, even if the author were not there to witness the actual deed. Whilst clerics argued that the flesh was less important than the spirit in the life to come, fleshly considerations were still important to social status among the secular elite in this life. It is relatively safe to assume, therefore, that if anything could be done to improve the appearance of an injured or disfigured face, recourse might be had to the appropriate persons. Otherwise, as we have seen, the main option was to conceal the injury as far as possible. This chapter, therefore, will explore the possibilities, in some specific cases of head and facial injury, for treatment and/or rehabilitation. Before doing so, however, it is important to try and establish the nature of medical and surgical knowledge in early medieval Europe, in order to provide a broader context for the few cases that have survived in the evidence.

This chapter began life at the Leeds International Medieval Congresses in 2013 and 2014, where it benefited from the insights of varied audiences.

(C) The Author(s) 2017

P. Skinner, Living with Disfigurement in Early Medieval Europe, DOI 10.1057/978-1-137-54439-1_7 


\section{Looking for Early Medieval Surgery: A Needle IN A HaYSTACK?}

The early Middle Ages have not been considered a high point of medical knowledge or practice, nor does this chapter claim to offer a wholesale or comprehensive revision of existing scholarship. What is at issue here is the limiting force of older views such as Stanley Rubin's comment at a colloquium in 1986 that practitioners in Anglo-Saxon England "learnt their skills on a trial and error basis," and that "Their practice was an amalgam of empirical herbal techniques, Classical precedent and philosophy, ritual incantations with a very strong superstitious overlay, plus a very basic form of faith healing. Yet even among all this worthless matter a whisper of rational expertise can be determined" [my emphasis]. ${ }^{1}$ Sean McGlynn, too, seems to accept older views of medical expertise in the early Middle Ages when he comments that "the lack of medicinal knowledge and good practice could make even a minor wound potentially dangerous." 2 Peregrine Horden is less judgmental at least, but comments that our knowledge of medical practice pre-1200 is "all mutability," that is, there is no overarching scheme to mirror later scholastic medicine, but early medieval medicine "is, to some extent, ancient medicine (e.g. Dioscurides) continued by other means." 3 The major problem dogging the study of early medieval medicine, however, is hindsight - all of these authors know what happened in the twelfth and thirteenth centuries, when ancient texts and "rationality" were restored to Western medical practice after a long hiatus. But whilst the period c.400-c.1100 in Western Europe clearly did see a comparative dip in scholarly activity around medical knowledge, this does not mean that medical practice was therefore in some way "inferior." 4

An example of such ancient knowledge was excerpted and collected, and is visible in three receptaria preserved in the monastic archives of St Gall and Bamberg. Published by Julius Jörimann in 1925, two (which I shall term St Gall $A$ and $B$ ) are preserved (one incompletely) in Codex Sangallensis 44, a ninth-century collection written in Carolingian miniscule, and the third in Bamberg, dating to the tenth century and written in fine book hand. The Bamberg codex shares some common material with the earlier part (i.e. before the section with the recipe books) of the Codex Sangallensis. ${ }^{5}$ Jörimann suggests that these collections contain remedies for the use not of a "professional" doctor, but a monk with medical skills who could apply the recipes to his brethren in the cloister. ${ }^{6}$ His comment again reveals the explicit devaluing of practitioners vs. professionals 
in early medical history, but if these collections were indeed for actual use, the inclusion, in two out of the three, of gynecological recipes suggests that the copying and excerpting were not entirely shaped by likely patients.

What is interesting about the texts, however, is the apparent concern for personal appearance that emerges from them. Arranged in a head-totoe order, St Gall A contains remedies for stains (maculas) in the eyes, head injuries and injured noses (nares vulnerosas), lesions near the eyes and nose and pustules. St Gall B, whilst incomplete, adds remedies for scurf, lice and fleas in the hair, eyes that have been hit/injured (ad percussum oculum) and chapped lips and face in the winter. Bamberg addresses baldness, alopecia and scurf, and has a recipe to remove stains on the face. There are parallels here with the Anglo-Saxon leech books, which Rubin long ago suggested demonstrated a high concern for personal appearance. ${ }^{7}$ These medical texts, at the very least, theorized what to do to improve facial appearance: there are numerous remedies found in the Anglo-Saxon Leechbook for pustules, ulcers and blotches on the face, as well as for loss of hair. Perhaps most surprising of all is a surgical procedure for the correction of disfigurement caused by a hare lip:

For hare lip: pound mastic very small, add the white of an egg and mingle as thou dust vermilion, cut with a knife the false edges of the lip, sew fast with silk, then smear without and within the salve, ere the silk rot. If it draw together, arrange it with the hand; anoint again soon. ${ }^{8}$

That the copyist of the Leechbook included surgery such as this may be linked to the likelihood that any such operation would have been carried out on an infant or young child. A risky action, perhaps, but if it succeeded, it might assist the child to attain full social adulthood, particularly if it also ameliorated any speech impairment caused by the condition. ${ }^{9}$ Throughout the book our attention has been drawn to the fact that the writers of early medieval narratives and law codes cared about, observed and imputed meaning to facial appearance. Whether or not the Leechbooks and continental medical texts represent evidence of medical practice is rather less important than the fact that they correspond, in their ideas about the face, with other sources. Gariopontus' revolutionary head-to-toe Passionarius was known in England by the end of the eleventh century, and extracts were also copied into the Old English translation of the Peri Didaxeon. ${ }^{10}$ Despite the obvious scholarly interest in such texts, we should not discount the possibility that some remedies and procedures were actually 
tried out. ${ }^{11}$ Early medieval non-medical sources, such narrative texts, laws and archaeology, after all, point to a rather more sophisticated medicaland surgical-environment than has previously been credited in the early medieval period.

Medicine and surgery have been understood and studied as almost separate areas of care. Surgery had a long history, from antiquity, ${ }^{12}$ of being viewed as a separate, practical-and subject-branch of medicine. The distinction seems to have disappeared in early medieval Western Europe, judging by examples to be discussed below, but persisted in areas of Muslim rule, where the inheritance of antiquity was far more direct. The difference between the two fields is expressed most clearly in texts such as that of the Egyptian physician Ibn Ridwan (d.1068), who commented:

I divide the teaching of medicine into two parts: one is theory, which is to be studied either from the books of Hippocrates or those of Galen... The other is practice, by which I mean the study of bone-setting, the restoration of dislocations, incision, suturing, cautery, lancing, eye remedies and all other manual procedures. ${ }^{13}$

Put simply then, surgery was conceived as the care of the external body, a response to trauma, wounding, or the visible lesions caused by disease. The knowledge required to do this effectively might vary between practitioners, and there were certainly, in the Muslim world, texts instructing the surgeon, but the overarching framework for understanding early medieval surgery in Western Europe before c.1200 is as a practical skill, rather than a theorized vocation. The description of surgical procedure on view in Bald's Leechbook, for example, does not link it in any way to the general health of the person being operated on. But this text is exceptional in many ways, both in terms of its content and the level of scrutiny it has received from historians. ${ }^{14}$ In fact, early medieval European medical texts more usually feature lists of remedies, rather than the surgical procedures that are included in Bald. Rubin concedes that "even in AngloSaxon times there was some form of medical education." 15 And as we shall see, the early medieval doctor was expected to be a general practitioner of sorts, skilled in all aspects rather than specializing in one.

The distinction between medicine and surgery resurfaced in Europe and was reinforced during the course of the twelfth and thirteenth centuries. The advent of "rational" surgery, evident in western writers such as Theoderic of Bologna, confined surgical intervention to a last resort after 
diet, regime and medicines had been tried. ${ }^{16}$ The invisibility of early medieval surgeons in Western Europe, then, stems from the fact that documented specialism in a field only became common after 1100. Again, this has led to relative neglect, until relatively recently, on the part of historians, in tracing earlier evidence of surgical practice. ${ }^{17}$ Yet the early Middle Ages in Western Europe are not devoid of surgical texts, and Horden's own work has demonstrated that looking for information in other types of early medieval sources can produce quite startling insights into the sophistication of care and cure at this time, extending even to "alternative" therapies such as the use of music. ${ }^{18}$

Even if we do not have early medieval references to "professional" surgeons, therefore, the existence of such a group of skilled practitioners should not be dismissed as fanciful. Clare Pilsworth's work on the apparent prestige of medical experts in Lombard Italy suggests that competent practitioners existed long before the advent of the "rational" surgical profession in the late twelfth and early thirteenth centuries, and at the very least were viewed as respected members of their local communities. ${ }^{19}$ Moreover, the definition of a medical profession, commonly thought to be a phenomenon of the twelfth and thirteenth centuries, needs to be reconsidered in the light of numerous examples of paid doctors earlier on, and the evidence, albeit slim, of regulation and of doctors being encouraged to indemnify themselves against accusations of malpractice. The early Welsh poem, the Prophecy of Britain, famously declares of the battle between Britons and Saxons, "no fee for the doctor will come of their deeds." Rhetorical flourish or evidence of potentially redundant battlefield surgeons? ${ }^{20}$ We shall return to this issue.

As Horden, Banham and others have demonstrated, the copying and excerpting of medical texts continued throughout the early middle ages, ${ }^{21}$ but the relative paucity of material, in comparison with the intensity of activity in the twelfth century, ${ }^{22}$ is revealing: it is unlikely that text survival is a reliable indicator of the levels of competency or the distribution of practical competence. Ideas about wound care, on the other hand, occur frequently in non-medical texts: a rich source to mine is the abundance of legal codes from early medieval Europe, which list in some detail the penalties to be imposed for various injuries to the body. ${ }^{23}$ Whilst the severity of the wound, and its care, might be determined by bleeding-several early medieval laws draw a distinction between a wound that could or could not be staunched, ${ }^{24}$ - the laws are primarily concerned with the compensation payable for injury, and this financial penalty might also include calling for a 
doctor, ${ }^{25}$ or offering the victim some kind of sick maintenance. ${ }^{26}$ The clear overlap between versions of the same code, and between codes intended for different ethnic groups, prevent any sense of where such assistance might be more common, but all assume the existence of paid doctors (medici) to attend to injuries and/or to testify to their severity. This legal function mirrors Pilsworth's findings about the status of Lombard doctors. The esteem in which medics were held in this period is also possibly illustrated by the elevation of one, Deroldus, to the bishopric of Amiens in $929 .{ }^{27}$

\section{Healing in Action?}

At the same time as providing evidence of the existence of such trusted figures, the source material is frustratingly reticent about describing treatment practices. We are certainly not lacking in references to serious and superficial head and facial wounds (one has only to read Gregory of Tours' accounts of the endemic violence in Merovingian Francia $)^{28}$ but their concern, as we have seen, is less with the medical after-effects than with the responses that such wounds might elicit. A rare reference to medical treatment in Gregory in fact indicates that not all care was designed with beneficial effects in mind. Describing the arrest and downfall of Count Leudast of Tours, whose earlier mutilation was discussed above, Gregory reports that Queen Fredegund's men struck him on the head, cutting away most of his hair and scalp, and that he broke his leg in the process of fleeing his assailants. King Chilperic ordered that he receive medical attention ( $u t s t u$ devetur a medicis) until his wounds were cured, and then be put to lingering torture. When his wounds began to fester, Leudast was put to death on the orders of the queen. Gregory, whose own hostile relationship with Leudast was longstanding, expresses satisfaction at the death. ${ }^{29}$ Exploring the medical aspect of this account, however, the idea that a victim should be rendered fit enough to undergo further bodily punishment (Miller's "keep him alive for scoffing"?) does not appear to have caused any moral qualms on Gregory's part, and we do not know what the doctors implicated in this process thought of their orders. ${ }^{30}$ Presumably fear of the king and queen prevented protest, but the fact that only the wounds inflicted by the torturers are described as festering signals some competence of care at least, even if the ethics of the doctors' actions were questionable.

We see doctors in action in early ninth-century narrative accounts from Francia as well. When a fragile wooden arcade collapsed on Emperor Louis 
the Pious and his attendants in 817 , the king's bruised chest, injury to the back of his right ear and injury to his groin from a piece of flying wood were quickly dealt with "through the diligence of his physicians (medicorum)" and he was able to go hunting less than three weeks later. ${ }^{31}$ Louis's eponymous son, Louis the German, also met with misfortune, falling from a second storey; not giving his physicians (medici) enough time to heal him, however, he then had to have rotting flesh cut out from his (unspecified) wounds and remain laid up at Aachen. ${ }^{32}$ "Rotting flesh" may serve as a catch-all term for any type of infection, but this passage is valuable for confirming that "the same medici" had to deal with the surgical intervention-it is tempting to surmise that if the distinction between medical and surgical practice was not manifest at the level of court physicians, the same was also true lower down the social scale. ${ }^{33}$ The sources are silent, however, on the care received by King Louis IV of Francia on his deathbed in 954 after a fall from a horse. Flodoard reports that he was gravely injured, and lay sick at Rheims for a long time, afflicted by "elephantiasis," before dying. Given that this term was used by ancient physicians and their medieval heirs as a term for leprosy or skin lesions in the early Middle Ages, however, one wonders whether Louis' fall was a result of an existing illness, rather than its cause. ${ }^{34}$

Leaving the court environment, physicians become rather more elusive (except in stock tales about their inability to provide a cure in hagiographic texts, which were all-too-often utilized by earlier historians of medicine as evidence of the "ignorance" of medieval medicine). ${ }^{35}$ We have already seen that early medieval lawcodes contained detailed clauses about injuries to the head and face. ${ }^{36}$ When looking specifically for medical practice in the laws, it is striking just how many references to medical practice and medics there are. These can be broken down into earlier regulation of medical practice, and the evidence for doctors being called in to treat illegally-inflicted wounds and/or attest to their severity.

Book XI of the seventh-century Visigothic lawcode, for example, has no less than eight clauses relating to physicians and their practice, including bleeding and the removal of cataracts from eyes (for which the reward is high: 5 solidi.) The laws assume that a medic will be called to treat the sick and wounded, recognize those who pass on their knowledge to others, and offers protection to the doctor whose patient dies. ${ }^{37}$ Elsewhere in the code, wounds requiring compensation are categorized as slight, drawing blood or down to the bone. ${ }^{38}$ This code has of course been recognized as one of the most "Roman" of lawcodes, and the regulation 
of physicians echoes-but does not reproduce, textually, Book 13 of the Theodosian lawcode. (The latter regulates the appointment of doctors and their exemption from municipal and public office, rather than their practice as such. $)^{39}$ At a most basic level, even if the Visigothic kingdom was not teeming with doctors, it is clear that the rhetoric of royal authority in the lawcodes was thought to be enhanced by encouraging their practice and, crucially, the training of future generations. The flourishing intellectual and medical culture of Al-Andalus, then, may have benefited from and built on pre-existing foundations of practice.

Almost contemporary Lombard law, whilst it does not regulate medics in quite the same way, nevertheless reiterates, from Rothari's edict in 643 to Liutprand's recension in the early eighth century, that "He who causes injuries should seek the doctor (Qui plagas fecerit, ipse querat medicus $[$ sic] $)$." Moreover, the assailant is charged to pay the doctor's fees and tip "as will be decided by learned men (per doctos homines arbitratum fuerit)." 40 "Learned men" might suggest either those versed in the law or previous cases, or may hint at other doctors being called in to give their opinion on the injury itself before costs of care were calculated. A striking element in these laws is the fact that the doctor is assumed to be called for injuries to slaves or semi-free (and the fee and tip excluded from the compensation amounts quoted), but is not mentioned in the list of compensations for injuries to freemen. Why should this be? One possibility is that medical care here is being expressed as an additional cost in the restoration of an asset, that is, the slave or semi-free peasant, to working order.

Both codes indicate, therefore, that doctors were thought to be available, and assume that medici would be able to treat wounds, that is, undertake the work that would later be left to surgeons. ${ }^{41}$ The clauses considered so far are less explicit (with the exception of the clause on cataract removal) about the treatments they offered. For more detail we have to turn to the laws of the Alemans. Although the attribution of this code in different manuscripts to an unidentified King Clothar (II - 613-628, III 657-673 or IV - 717-719) or to Duke Lantfrid (709-730) makes precise dating of the laws difficult (their modern editor plumps for early eighth century) ${ }^{42}$ their medical content is quite striking. Law 57 [59] is worth drawing attention to for its detailed, gradated description of head injury and to the role of the doctor in providing care and subsequent testimony:

1. If anyone out of anger hits another, called "pulislac" by the Alemans, let him compensate with one solidus. (Si quis alium per iram percusserit, quod Alemanni "pulislac" dicunt, cum uno solido componat). ${ }^{43}$ 
2. If blood is shed, that touches the ground, let him compensate with $1^{1 / 2}$ solidi. (Si autem sanguinem fuderit, ut terra tangat, conponat solido uno et semis.)

3. If he should hit him so that the head appears and is scratched, he compensates with 3 solidi. (Si autem percusserit eum ut testa apparet et radatur, cum 3 solidis componat.)

4. If a broken bone should be taken from the head, and that bone makes a sound in a shield across a road 24 feet wide, let him compensate with 6 solidi. (Si autem de capite ossum fractum de plaga tullerit, ita ut super publica via lata 24 pedis in scuto sonaverit ille ossus, cum 6 solidis componat.)

5. If however the doctor loses [the bone] and cannot present it, then he should bring two witnesses who saw that bone was taken from the wound, or the doctor himself should prove that it is true that bone was taken from the wound. (Si autem ipsum perdit medicus et non potest eum praesentare, tunc duos testes adhibeat, qui hoc vidissent, quod de illa plaga ossus tullisset, aut ille medicus hoc conprobet, quod verum fuisset, quod de ipsa plaga ossus tullisset.)

6. If the head is scalped/cut into, so that the brains appear and the doctor has to touch them with a quill or a cloth, 12 solidi should be paid. (Si autem testa trescapulata fuerit, ita ut cervella appareant, ut medicus cum pinna aut cum fanone cervella tetigit, cum 12 solidis conponat. $)^{44}$

7. And if the brain should come out of the wound, as often happens, so that the doctor staunches it with medicine and silk, and afterwards [the victim] recovers, and this is proven to be true, 40 solidi are to be paid. (Si autem ex ipsa plaga cervella exierunt, sicut solet contingere, ut medicus cum medicamento aut cum sirico stuppavit, et postea sanavit, et hoc probatum est., quod verum sit, cum 40 solidis componat. $)^{45}$

A very similarly-structured list is included in the Lex Frisionum, Title XXII, compiled nearly a century later. This, though, has some important differences. It envisages that head injuries could cause impairment:

1. If anyone hits someone else on the head out of anger, and makes him deaf, he should give 24 solidi. (Si quis alium per iram in capite percusserit, ut eum surdum efficiat, 24 solidos componat.)

2. If he is made mute but can nevertheless still hear, 18 solidi should be paid. (si mutus efficiatur, sed tamen audire possit, 18 solidos componat.)

3. If anyone hits someone, which they call "durslegi", he should pay $1 / 2$ solidus compensation. (Si quis alium ita percusserit, quod "durslegi" vocant', dimidium solidum componat.)

4. If he should shed blood, he should pay 1 solidus. (Si autem sanguinem fuderit, componat solidum 1.)

5. If he should hit him so that the head appears, he should pay 2 solidi. (Si eum percusserit ut testa appareat cum 2 solidis componat.)

6. If the skull is perforated, he should pay 12 solidi. ( Si os perforatum fuerit, 12 solidos componat.) 
7. If his sword should touch the membrane around the brain, he should pay 18 solidi. (Si membranam, qua cerebrum continetur, gladius tetigerit, 18 solidos componat.)

8. If the membrane is ruptured, so that the brain can come out, he should pay 24 solidi. (Si ipsa membrana rupta fuerit, ita ut cerebrum exire possit, 24 solidos componat.)

71. If from the wound there comes out a bone of such size, that thrown into a shield across a public road its sound can be heard, 4 solidi should be paid. (Si de vulnere os exierit tantae magnitudinis, ut iactum in scutam trans publicam viam sonitus eius audiri possit, 4 solidis componatur.)

72. If 2 bones: 3 solidi;

73. If 3 bones: add one solidus;

74. If smaller bones but they sound in the shield, half the above payments. ${ }^{46}$

Clearly, the detailed clauses on head injury share much with the Alemannic model, but the Frisian laws are silent on the care of doctors until some later additions relating to injuries to the stomach (the "judgment of Wulemar," 1 and 2). As we have seen from the Lombard material, however, the presence or absence of references to medics may not be determined by their relative accessibility in a particular region. The Lex Baiwariorum, for instance, repeats clauses about wounding, but the need to call a doctor"ut propter hoc medicum inquirat"-is only mentioned as a measure of the compensation to be paid. ${ }^{47}$

Slightly later in date, the regulation of medical practice also appears in the Welsh laws, with the role of the court doctor outlined in some detail. ${ }^{48}$ Dating anywhere between the tenth and twelfth centuries, the laws outlining the duties of the king's physician (meddyg) provide some striking points of comparison with earlier laws. The court physician is supported by the king and queen in return for treating members of the court free of charge, except for the three "dangerous wounds"- a blow to the head reaching the brain, a blow to the body reaching the bowels and a broken arm or leg. For treating these, the medic can charge set fees, which are outlined in the laws. Further treatments, such as bleeding, applying herbs to swellings and applying "medication with red ointment" are also given set charges. ${ }^{49}$ What was this precious "red ointment"? Cule says it is a mistranslation of a treatment for a major blood vessel: if so, it would represent a substantial fee. ${ }^{50}$ We shall return to this issue.

Rather like the Visigothic laws, Welsh law advises the physician to take assurances from his patients' families before undertaking treatment, in order to avoid repercussions if the patient dies. And like the Alemannic 
codes, the doctor-and here we may be moving beyond simply the court physician-is also involved in disputes following serious injury. Again, the assumption is that the doctor should keep any extracted bone from a skull injury, so that if there is a dispute about its size (indicating seriousness of injury), he can "take a brass bowl, and let him set his elbow on the ground with his hand above the bowl, and if its sound is heard, $4 \mathrm{~d}$, and if it is not heard there is no right to anything." ${ }^{51}$ The physician's fees are also repeated, although there is a difference of two and a half pence per day between the food for the court physician and any other person!

The similarities between Welsh and earlier continental laws on these issues have not gone unnoticed. Although Thomas Glyn Watkin's extensive survey of Welsh legal history identified some possible lines of transmission (he notes, for example, that the Theodosian code was known in Britain, despite postdating the Roman withdrawal), they have remained brief comments in footnotes. Yet, medieval Wales was a cosmopolitan place, and had links not only with other Celtic regions such as Ireland and Brittany (all three sharing specific legal terminology relating to honorprice, as we have seen), but also with England and Francia, particularly the court of Gwynedd's links with that of Charles the Bald. ${ }^{52}$ The medical motifs visible in Welsh law might simply derive from a shared, IndoEuropean past that valued ritual (the clang of a bone in a metal receptacle) and had taboos (blood reaching the ground, polluting the kingdom). But I wonder whether they are in fact more valuable in demonstrating the earlier, oral stratum of the law as well, one receptive to the idea of speciallyappointed medical men, and aware that some wounds, and illnesses, just could not be cured? How far did shared medical ideas travel, particularly but not exclusively relating to head injuries? This is where the question of "red ointment"/"major blood vessel" comes in again, for the serious wound to a vein is included in Bavarian laws requiring the presence of the doctor. Does legal medicine represent medicine on the ground? I suggest that the ubiquity of references to doctors in some texts, their absence in others, and the occasional glimpse into practice argues against seeing these simply as textual reproductions.

\section{Medical Language}

Letters, too, offer a rich seam of what might be best-termed quasi-medical information and the use of medical metaphors. Like their Biblical models, these tend to contrast earthly healing with spiritual rewards, but are 
nevertheless useful for exploring recurring themes. Charlemagne's biographer Einhard reflects on whether the "wound" of his wife's death will ever heal over to a scar with the medicine of consolation. ${ }^{53}$ In Gerbert of Aurillac's letters, among others, there is ample evidence of medical terminology being utilized in a metaphorical sense to persuade erring members of the church to have a care for their spiritual health. For example, in a letter to Thibaud, Bishop of Amiens in 976, he rebukes the bishop for refusing to attend synods, and says that "The reverend 'physicians,' well acquainted with your ailments... and that pseudo-archbishop who... infected you as if by certain contagion, agreed upon the dishonor as far as you are concerned... the judgment of Pope Benedict VII found you incurable." ${ }^{54}$ A letter written for Bishop Dietrich of Metz in 984 condemning Duke Charles for his betrayal includes: "you pour forth the disease of your utterly wicked heart... Eager to care for your wounds, hitherto I poured oil and wine upon them by mixing soft words... unless you repent, by the sword of the Holy Spirit, entrusted to me, I will cut you off along with your putrescent members." A wandering monk, too, was to be given "honeyed doses, according to the manner of a good physician lest, when the bitter antidotes are administered, the patient... should begin to tremble for his safety." 55 In terms of his own medical practice, as we have seen, Gerbert drew a line between knowledge, of which he had plenty, ${ }^{56}$ and practical remedies, which he was reluctant to put into effect. ${ }^{57}$

Slightly later, Fulbert of Chartres (c. 970-c.1030) envisages a more robust, "surgical" intervention to bring Bishop Hubert of Angers, whom he had excommunicated, to penitence. In his letter to the bishop, Fulbert refers to "the scalpel of prudence (falce discretionis)" cutting away Hubert's sins, before launching into a lengthy series of medical metaphors for treating the now open "wounds." ${ }^{58}$ Metaphorical, certainly, but hinting at some very simple wound management open to those less well-educated than Fulbert and his circle: cutting away bad flesh, cauterizing but then applying emollients to the wound before adding honey, whose antiseptic qualities both protected and healed..$^{59}$ A letter of 1031 of Ebbo, schoolmaster at Worms cathedral, also exemplifies the common use of medical terminology, but illustrates the division, already met in Thietmar, between the relative unimportance of the body when compared with the soul: "For as it says in proverbs, a friend out of duty disagrees with the doctor, for whilst [the doctor] can heal the scars of the body, so [the friend] if he wishes well can cure the sicknesses of the soul." 60

Although medieval letters were written with an eye to demonstrating the writer's erudition and learning as well as conveying information and 
maintaining social relations, it is clear that their mainly clerical authors combined Classical allusions, biblical topoi and familiar home remedies to articulate their spiritual lessons. They are very comfortable with medical language; Orderic Vitalis, for example, terms the evangelist Luke the spiritualis archiatros or chief doctor of souls, and opined that, "A wise physician treats a sick man with a mild medicine, for fear that if he goads the sick man with the pain of too drastic a remedy he may kill instead of curing him." ${ }^{\prime 61}$ Here he is again referring to the care of souls, but he is also informative on some of the medical care for the body available in his own day, good and bad. His famous portrait of Ralph, the "Ill-Tonsured," is of a skilled medic who had "spent much of his time out of the study in the battle-field," (and so by implication was ill-suited to be a monk, hence his nickname?) and could treat victims of disease and accident. Operating as Ralph was during the latter part of the eleventh century and early twelfth, Orderic's text is valuable evidence that the split between medic and surgeon had not yet occurred. By contrast, the personal physician of King Henry I of France, he reports, was called "Blockhead" (Surdus-literally "Deaf"). Although he prescribed the ailing king a medicine, Henry died after drinking water: presumably the attack on the doctor was for lack of care or close observation, rather than the prescription itself. ${ }^{62}$

Self-care of sorts features in the twelfth-century Life of St Ulrich of Zell (d. 1093). It recounts how the prior gave himself a severe headache though his long, nocturnal vigils and his continuous work writing (per longas vigilias noctium, per scribendi laborem continuum, gravissimum capitis dolorem incurrebat). Not realizing this was a divine test, he decides to self-treat, washing his head "several times" with wormwood (aliquoties caput lavit absinthio). But he accidently pierced his eye with the stick (festuca) with which he was applying the remedy, and could not get it out. For six months he wept copious tears (guttatim effluxit) from the eye, but recognized that this temporary lack of external light and vision was a test to make him see the inner light more clearly (non est. contristatus pro exterioris luminis detrimento: quia quanto carnalis visus obscurior, tanto mentis acies ad contemplandum superni luminis claritatem fuerat perspicacior). ${ }^{63}$

\section{Case Study: Serious Head Injury in Battle}

All of this tangential evidence suggests that basic remedies were known and doctors were available (for a fee), and that many of their procedures, whilst clearly empirical, were not entirely without skill and knowledge. 
Removing bone from skull injuries, for example, was clearly understood to relieve pressure on the brain and may have been a widespread practice, whether or not the dura mater had been punctured. Whilst thirteenthcentury surgical manuals such as that of Theoderic of Bologna (c. 1267) urged haste in dealing with bone fragments, they were clearly not introducing a new method of treatment. ${ }^{64}$ Indeed, a clause in the midthirteenth-century Assizes of the Kingdom of Cyprus explicitly criticizes any doctor who did not know how to undertake this procedure competently: "should the doctor not have known how to open the wound, but treated it in such a way that the fractured bones came into contact with the brain," resulting in the patient's death, the doctor was liable to pay compensation. ${ }^{65}$

Whilst surgical texts might be lacking from the early medieval period, surgical knowledge clearly was not. Archaeological evidence from early medieval sites reinforces the evidence of competent surgery, and demonstrates that even serious head wounds were survivable, and that some must have been treated. Two warrior burials recently found in central Italy showed severe, but partly healed, head traumas. ${ }^{66} \mathrm{Had}$ these men received care from a surgeon? Certainly there would have been a need to remove splinters of skull, and in a case from the cemetery of the deserted medieval village at Wharram Percy, Yorkshire, there was some evidence of additional trepanation. ${ }^{67}$ This individual, dating from the tenth/eleventh century, is particularly exciting, as the location of the cemetery suggests that there was access to medical care in a relatively rural setting. Caution is required here, however, for the trepanation process can be interpreted as a religious ritual as well as one with a curative aim. Yet a sample of Anglo-Saxon cases studied by Parker suggests that, pagan or Christian, the procedure had been carried out with a medical aim as well as or rather than a ritualistic one, and there was a high success rate, evidenced by the partial healing evident in many of the skulls. Parker does not, however, speculate as to the reasons for the trepanning: blunt force injury and the need to access impacted bones is not mentioned at all. ${ }^{68}$ Exploring the later world of the crusade surgeon, Piers Mitchell cites a survey of cemetery evidence dating from the sixth to eighth centuries in Germany, in which approximately thirty of the deceased had cranial fractures and three-quarters of these had healed, again indicating survival. ${ }^{69}$ As Mitchell comments, further work on archaeological sites can only expand the sample of remains to inform our knowledge of the survivability of head injuries, whether sustained in warfare or through rather more mundane accidents. Blunt force cranial 
injury, of course, is not quite facial disfigurement. Nor does it all have to be the result of interpersonal violence (although it is often reported as such). Falls, and items falling on the head, could produce equally serious breakage of the skull.

More likely causes of disfigurement were assaults with bladed weapons: we have already met one or two of these. Literary sources portray survivors, such as Wulf Wonreding in Beowulf, who, though injured by a "keen wound" from a sword to his head through his helmet, was nevertheless "bound up" and recovered from it. ${ }^{70}$ Bernard Bachrach, basing his discussion on Rabanus Maurus's ninth-century text De Procinctu Miliciae, suggests that infantry soldiers were trained to jab short swords and cause puncture injuries, first at the head and face of the enemy, then at other parts of his body. This, he argues, was a more effective means of disabling and killing than using a slashing motion with the sword, which risked hitting only bone and shield and possibly one's own comrades. ${ }^{71}$ Yet Rabanus drew heavily on the fifth-century Roman author Vegetius's De Re Militari, which may explain his emphasis on Roman-style short swords. Slashing injuries in early medieval skeletal remains attest to longer weapons in individual combat. Archaeological studies seem to concur that the "primary target on the body" in close combat was the head which, if the individual was lacking or had lost his helmet, was the least protected part of his body, ${ }^{72}$ and remains quite commonly display blunt-weapon injury to the skull (such as might have been made by staves or spear shafts) alongside blade injuries. The potential for bruising and superficial cuts and lacerations, however, was greater than is revealed by the archaeological evidence, which mainly picks up the blows that hit home to the bone in a fatal, or near-fatal manner. ${ }^{73}$ Earlier sources rarely describe these in much detail ${ }^{74}$ but the literary and rhetorical skills of later poetry make much of such glancing blows, emphasizing the dangers of hand-to-hand combat. Robert of Courcy was wounded and lost his right eye in battle. ${ }^{75}$ Another type of head wound that shows up in the evidence is a direct hit by a projectile, whether an arrow in the face, often the eye area, or missiles such as stones either thrown from above or shot by machine. ${ }^{76}$ Arrow wounds were particularly difficult to treat, and those recorded in the written evidence were usually fatal, compounded, in many cases, by the difficulty of removing an arrowhead that might be barbed or poisoned. ${ }^{77}$ Richard of Acerra's arrow wound through both cheeks, discussed above and apparently successfully treated by a "medicus" and two female assistants, seems an entirely exceptional case when compared with the many full-frontal 
arrow strikes documented in the evidence. Richer son of Engenulf of Laigle was fatally wounded just beneath the eye by an arrow shot by "a certain beardless boy."78 Hugh, earl of Shrewsbury, despite being "clad in iron from the top of his head to the souls of his feet," was hit in the right eye by an arrow that penetrated his brain and killed him when fighting pirates from the Orkneys, "so that he fell mortally wounded into the sea." 79

\section{Blinding, Disfigurement and Aftercare: Living with a Changed Face}

If the theatre of warfare seems an obvious place to look for medics at work, the many examples of judicial mutilations and other blindings scattered throughout this book also demand attention as potential theatres of surgery. If the idea was to inflict a lasting punishment, the person needed to heal sufficiently to act as a living example to others. Branding was its own form of cautery, but were cut wounds - ears, noses and lips-also cauterized, as some of the metaphorical material explored above envisages? Limited evidence of the use of cautery has emerged from an eighthtenth-century grave in Pisa, but the report authors' speculation as to why it was used relies upon evidence from medical texts that were unknown in the West at this date. ${ }^{80}$

Blinding could be carried out without recourse to extraction of the eyes, but most of the examples do seem to involve heated brands or spiked implements, and as we have seen, care was needed to ensure these did not penetrate beyond the eye sockets and kill the unfortunate victim, even if the eyes were "discrete and as such neatly and discretely extractable" in Miller's words. ${ }^{81}$ But what happened next? In the extended scene recounted by Psellos, the two victims are "left to rest" after their ordeal, but presumably they might seek assistance to deal with the pain and bleeding. Anna Komnena relates that the blinded rebel Nicephorus Diogenes was "frantic with pain" after his ordeal. ${ }^{82}$ The most detailed account of possibly medical intervention, however, occurs in a hagiographical context. I alluded above to the case of Ailward of Westoning, pictured in the Canterbury cathedral Becket windows as the victim of an unjust blinding and castration, and cured by the saint. In two narrative text versions of the miracle, some form of aftercare treatment with an emollient, wax and bandages wrapped around the victim's eye sockets is mentioned. William of Canterbury reports that Ailward had a vision of St 
Thomas ten days after the blinding, and feeling his left eye itching ( $p r u$ riente sinistro oculo) he scratched at the wax and emollient that had been applied to eliminate the pus (scalpens ungue ceram summovit et malagma quod appositum fuerat ad purulentias extrahendas). ${ }^{83}$ Does this add veracity to the miracle story by introducing a "realistic" medical detail, or was this apparent "sealing" of the sockets a standard practice once eyeballs were removed? Benedict of Peterborough's slightly later account adds the detail that Ailward's eyes were bandaged (as he wonders whether his vision will come true once the bandage is removed), but confuses the issue too. Whilst William separates out the wax and the emollient, Benedict combines them into "waxy emollient (malagma cereum)" and adds that it had been applied "either to extract the pus from the empty sockets or to close the lids themselves (quod sive ad extrabendas orbium vacuorum purulentias seu ad ipsa cilia claudenda fuerat appositum)." 84 Certainly there is other limited evidence of bandaging being applied after blinding (in Anna Komnena's accounts), but whether this was to assist in healing, or simply an aesthetic choice to cover the wounds is never stated.

Focusing on the aesthetic demands a brief consideration of cosmetic aids. Demaitre has noted that the later Middle Ages saw an upsurge in medical texts dealing with apparently minor skin conditions and lesions. Remedies for ulcers and pimples on the face feature in the fourth-century Herbarium of Pseudo-Apuleius, translated into Anglo-Saxon in England in the tenth, and in Bald's Leechbook, but they were intended to heal such conditions, not conceal them. ${ }^{85}$ There is no consideration in this text of concealing or reducing scarring, for example. The rising concern with appearance may, however, be indicated by the numerical increase in such recipes, from three in the Apuleius to nineteen in the Leechbook. Specific concern with cosmetic appearance seems to have been focused on women: the twelfth-century De Ornatu Mulierum (On Women's Cosmetics), produced in Salerno in the twelfth century, starts with a series of recipes about hair (both conditioning and colouring, and depilation) before moving on to the face. Adorning the face, the text points out, "embellishes even ugly women (deformes mulieres palliat)." ${ }^{86}$ There follow recipes for diminishing blotches and freckles, whitening the complexion, curing scabies and attending to sunburn, but again, dealing with the after-effects of disfiguring conditions or scars is not considered explicitly. ${ }^{87}$ It seems that concealing facial scars with preparations was not, yet, a technique to "pass." 
Modern surgical care packages for disfigured people address not only the physical challenges their acquired disfigurement presents, but also the psychological trauma of waking with a new face (a trauma that, arguably, is repeated several times if surgery takes place in stages). To what extent is there any evidence of emotional or psychological support in the early Middle Ages? From the preceding discussion, it seems that in the early Middle Ages the circumstances of the disfiguring injury strongly shaped responses toward it, a phenomenon that arguably persists today. Military heroes (even unlikely ones like Bishop Michael of Regensburg, discussed above) or unjustly or illegally injured people (mutilated hostages) evoked some pity or sympathy and even-in the case of Genoese archers-financial support. Those who brought their disfigurement upon themselves, however, including not only criminals (like Septimina and Droctulf) but also irresponsible youths (Young Charles), seem to have been given rather shorter shrift. Ailward, according to Benedict's account, spent a day in Bedford sitting against the wall of a house "without any favor of humanity being shown towards him (nullo sibi collato humanitiatis beneficio)." Here the pathos of the broken man and his accompanying young daughter is designed of course to evoke even more pity before the miraculous intervention of Thomas.

Many cases feature those who were already socially visible elites, whose fate might usefully serve as an object lesson in humility. But their changed circumstances could also bring new opportunities. This is at least the tenor of Anna Komnena's report of the blinded Nicephorus, mentioned earlier. After withdrawing to his estates (wealth clearly cushioned the blow of his fall from favor), Anna recounts that he "found satisfaction... devoting all his energies to the study of ancient literature, read to him by others. Deprived of his own sight, he used the eyes of strangers for reading... Later he...even studied the celebrated geometry (an unprecedented feat) by getting a philosopher he had met to prepare the figures in relief. By touching these with his hands he acquired knowledge of all the geometrical theorems and figures. Thus he rivaled Didymus... I myself have seen the man and marveled at him..." 88 Anna's text is a classic example of the "triumphing over adversity" model, yet her account also objectifies Nicephorus, particularly that last sentence that sets him up almost as an exhibit to be visited and "seen." 89

No doubt Nicephorus's already high status and obvious wealth (he retired to his estates) cushioned the blow of his sightlessness, as well as persuading Anna to visit him. Lower-status victims of disfigurement 
were in a much more vulnerable position, and living with their condition required that they promote a fascinating back-story to make it into the written records at all. Walchelin the badly-burnt priest is a case in point, emphasizing the supernatural origin of his wounds (and thus again inviting wonder, not rejection). Ailward's initial day of dejection in Bedford, albeit a hagiographical tool to evoke pity in the reader, probably reflects far more accurately the social norm of living with an acquired disfigurement if one were only a peasant farmer. Yet another hagiographic text featured an alternative outcome. The eleventh-century Life of the sixth-century St Cadog of Wales features a "rustic" who dared to look through a spyhole to the tombs of Cadog's disciples in a Scottish monastery, despite the warnings of the custodian priests that Cadog would punish him for his presumption: "Go," they say, "and may St Cadog make a sign of his revenge appear on you [Vade, et faciat sanctus Cadocus quatinus signum ultionis appareat in te]." Peering through the opening, the peasant's eye immediately "burst, and hung down his face suspended on the optic nerve [crepuit, et per neruum octicum facie tenus depependit]." Far from being defeated by this punishment, he subsequently "traveled from place to place throughout the province of Lintheamina, covering his broken eye. And many people gave him alms, in order that he should show them the torn apart eyeball. And from this more and more of his countrymen learnt to fear God, and reverently worship him through his saint [Giravit equidem itidem rusticus de loco ad locum per totam provinciam Lintheamine, erutum oculum tegens. Plures mercedem ei largiebantur, ut eis diuulsum ocelli orbiculum ostenderet. Exin magis ac magis compatriote discebant Deum metuere, et cum sancto suo reverenter glorificare]." 90

For the rustic, his impairment represented an opportunity, and whilst at first sight his wandering and seeking alms mirrors that of the blinded priest Wipert, discussed earlier, his showman-like action in concealing and then revealing his eyeball seems to represent social elevation of a kind rather than humiliating punishment. For those already in socially-elevated positions, however, death was indeed written up as preferable to disfigurement or impairment (Emperor Michael, Luke of La Barre), but we cannot discount the idea that faith supported the survivors in ways that the texts just do not make explicit. (This, after all, was the purpose of hagiographic tales of exceptional cures.) Were people with disfigurements reminded that their humility or humiliation on earth would be rewarded in heaven, and did this help at all with the day-to-day battle of living with disfigure- 
ment? In the concluding chapter, the continuities and changes across time will be briefly considered as a starting point for more work on the history of disfigurement.

\section{Notes}

1. Stanley Rubin, "The Anglo-Saxon physician," in Medicine in Early Medieval England: Four Papers, ed. Marilyn Deegan and D. G. Scragg (Manchester: Centre for Anglo-Saxon Studies, 1987), $7-15$, quote at 9 .

2. Sean McGlynn, By Sword and Fire: Cruelty and Atrocity in Medieval Warfare (London: Weidenfeld and Nicolson, 2008), 11.

3. Peregrine Horden, "Medieval medicine," in The Oxford Handbook of the History of Medicine, ed. Mark Jackson (Oxford: Oxford University Press, 2011), 51-2.

4. A recent and sustained polemic against such assumptions about the early middle ages is Clare Pilsworth, Healthcare in Early Medieval Northern Italy: More to Life than Leeches (Turnhout: Brepols, 2014).

5. J. Jörimann, Frühmittelalterliche Rezeptarien (= Beiträge zur Geschichte der Medizin, Heft 1) (Leipzig and Zurich: Orell Füssli, 1925).

6. Jörimann, Frühmittelalterliche Rezeptarien, 81.

7. Stanley Rubin, Medieval English Medicine (London: David and Charles, 1974), 147.

8. Leechbook I, in Leechdoms, Wortcunning and Starcraft of Early England, ed. O. Cockayne, 3 vols (London: Longmans and Green, 1864-6), II.19-26 (head, 17 recipes), 27-38 (eyes), 53-4 (facial blotches), 59 (hare lip), 77-81 (pustules and blotches), 155 (hair loss or excess hair).

9. I have alluded to the issue of congenital impairment in children above.

10. F. Eliza Glaze, "Gariopontus and the Salernitans: textual traditions in the eleventh and twelfth centuries," in "La Collectio Salernitana" di Salvatore de Renzi, ed. D. Jacquart and A. Paravicini Bagliani (Florence: SISMEL Galluzzo, 2009), 149-90, at 165. Online at http: / / coastal.academia.edu/FlorenceElizaGlaze / Papers/558742/_Gariopontus_and_the_Salernitans_Textual_ 
Traditions_in_the_Eleventh_and_Twelfth_Centuries_ [Accessed 21 August 2012]. On the OE Peri Didaxeon (British Library, Harley MS 6258 B, ff 55v-66v), see L. Sanborn, "Anglo-Saxon medical practices and the Peri Didaxeon," Revue de l'Université d'Ottawa, 55 (1985): 7-13.

11. Not only tried out, but in some manuscripts clearly collected for use "by any able and experienced individual, whether in the home, monastery or clerical community": Pilsworth, Healthcare, 93.

12. The preface to Celsus, De Medicina states that medicine is made up of diet/regimen (rictu), remedies (medicamenta) and operations (manu): cited in Michel Foucault, Care of the Self: the History of Sexuality vol. 3, tr. R. Hurley (London: Penguin, 1990), 100.

13. Ibn Ridwan, Useful Book, 103, 5-9, tr. A. Z. Iskandar, "An attempted reconstruction of the late Alexandrian medical curriculum," Medical History, 20 (1976): 243, quoted in Peter E. Pormann and Emilie Savage-Smith, Medieval Islamic Medicine (Edinburgh: Edinburgh University Press, 2010), 84.

14. M. L. Cameron, "Bald's Leechbook: its sources and their use in compilation," Anglo-Saxon England, 12 (1983): 153-182; id., "Bald's Leechbook and cultural interactions in Anglo-Saxon England," Anglo-Saxon England, 19 (1990): 5-12; Audrey Meaney, "Variant versions of Old English medical remedies and the compilation of Bald's Leechbook," Anglo-Saxon England, 13 (1984): 235-268; Richard Scott Nokes, "The several compilers of Bald's Leechbook," Anglo-Saxon England, 33 (2004): 51-76; Stephanie Hollis, "The social milieu of Bald's Leechbook," AVISTA Forum Journal, 14 (2004): 11-16; Maria A. D'Aronco, "The transmission of medical knowledge in Anglo-Saxon England: the voices of manuscripts," in Form and Content of Instruction in Anglo-Saxon England in the Light of Contemporary Manuscript Evidence, Papers presented at the International Conference, Udine, 6-8 April 2006, ed. by Patrizia Lendinara, Loredana Lazzari, and Maria A. D'Aronco, (Fédération Internationale des Instituts d'Études Médiévales, Textes et Études du Moyen Âge, 39, Turnhout: Brepols, 2007), 35-58

15. Rubin, "Anglo-Saxon physician," 8. Despite its air of disparagement, Rubin's is a useful overview.

16. E. Campbell and J. Cotton, tr., The Surgery of Theoderic, c. AD 1267 (New York: Appleton-Century-Crofts, 1955), Introduction, 
4 and 5. See more generally Michael McVaugh's influential study, The Rational Surgery of the Middle Ages (Firenze: SISMELEdizioni del Galluzzo, 2006).

17. Texts still dominate the field, however, as essays in the recent volume Between Text and Patient: the medical enterprise in medieval and early modern Europe, ed. Florence Eliza Glaze and Brian Nance (Florence: SISMEL-Edizione del Galluzzo, 2011), illustrate.

18. Peregrine Horden, "Religion as medicine: music in hospitals," in Religion and Medicine in the Middle Ages, ed. Peter Biller and Joseph Ziegler (York: University of York, 2001), 135-153, reprinted in id., Hospitals and Healing from Antiquity to the Later Middle Ages (Aldershot: Variorum, 2008); Music as Medicine: the history of music therapy since antiquity, ed. Peregrine Horden (Aldershot: Ashgate, 2000), including his "Commentary on Part II, with a note on the early middle ages," 103-108.

19. Clare Pilsworth, “Could you just sign this for me John?” Doctors, charters and occupational identity in early medieval northern and central Italy," Early Medieval Europe, 17 (2009): 363-388.

20. The Earliest Welsh Poetry, tr. Joseph P. Clancy (London: Macmillan, 1970), 109. The poem is thought to date to c. 930.

21. Debby Banham, "A millennium in medicine? New medical texts and ideas in England in the eleventh century," in Anglo-Saxons: Studies presented to Cyril Roy Hart, ed. Simon Keynes and Alfred P. Smyth (Dublin: Four Courts Press, 2006), 230-242; Peregrine Horden, "The year 1000: medical practice at the end of the first millennium," Social History of Medicine, 13 (2000): 201-219. See also Anne van Arsdall, "The transmission of knowledge in early medieval medical texts: an exploration," in Between Text and Patient, ed. Glaze and Nance, 201-216 and Maria Amalia D'Aronco, “How 'English' is Anglo-Saxon medicine: the Latin sources for Anglo-Saxon medical texts," in Britannia Latina: Latin in the Culture of Great Britain from the Middle Ages to the Twentieth Century, ed. Charles Burnett and Nicholas Mann (London: Warburg Institute, 2005), 27-41.

22. See Monica Green's report on her project to collate twelfthcentury materials at http://www.academia.edu/4613362/_ Medical_Manuscripts_from_the_Long_Twelfth_Century_ Manuscripts_on_My_Mind_News_from_the_Vatican_Film_ Library_No._8_January_2013_p._11 [Accessed 2 October 2013]. 
23. See above, Chap. 3 and below, Appendix 2; wound care is extensively discussed in Wounds and Wound Repair in Medieval Culture, ed. Kelly de Vries and Larissa Tracy (Leiden: Brill, 2015), and has already formed the focus of Wounds in the Middle Ages, ed. Anne Kirkham and Cordelia Warr (Aldershot: Ashgate, 2014). The latter, however, virtually ignores the period before 1200 .

24. Pactus Legis Salicae, XVII.7, ed. K. Eckhardt, in MGH Leges Nat. Germ., IV.1 (Hannover: Hahn, 1962), 78. It derives indirectly from a biblical model: a wound that could not be staunched, after all, would drip blood on the ground, polluting it and demanding expiation: Numbers 35:33.

25. Pactus Legis Salicae, XVII.7; Lex Salica Carolina, XXII.4, ed. K. A. Eckhardt, MGH LL nat. Germ. IV.2 (Hannover: Hahn, 1969). Doctors' fees are mentioned in Leges Langobardorum, ed. F. Bluhme in MGH LL, IV, ed. G. H. Pertz (Hannover: Hahn, 1868), Rothari cc. 79, 81, 82, 83, 84, 103, 106, 107. Ibid., Rothari c. 128 states that "he who struck the blow should seek the doctor; if he has neglected to do this, the man struck or his lord should find the doctor [and the perpetrator pays the bill]."

26. The victim in Irish law was eligible for sick maintenance by his/her assailant if s/he did not recover quickly: Fergus Kelly, A Guide to Early Irish Law (Dublin: Institute for Advanced Studies, 1988), 130. On early Anglo-Saxon provision, see Lisi Oliver, 'Sick maintenance in Anglo-Saxon law', Journal of English and German Philology, 107.3 (2008): 303-326.

27. The Annals of Flodoard of Reims, 919-966, tr. Steven Fanning and Bernard Bachrach (Toronto: Toronto University Press, 2011), 18.

28. GT, I.1; e.g. the regular removal of noses and ears (V.18, VIII.29, IX.38, X.15); the punishment of branding to the face (IX.38).

29. Above, Chap. 4, note 32; GTVI.32.

30. William Ian Miller, Eye for an Eye (Cambridge: Cambridge University Press, 2006), 151.

31. Annales Regni Francorum, s.a. 817: MGH SS rer. Ger., VI, ed. G. H. Pertz (Hannover: Hahn, 1895).

32. Annales Bertiniani, s.a. 870, MGH SS, I: Annales et Chronica Aevi Carolini, ed. G. H. Pertz (Hannover: Hahn, 1826): minus necessario curari a medicis sustinens, computrescentem carnem ab eisdem medicis secari fecit. 
33. Rubin, "Anglo-Saxon physician," 9, concurs that in England, too, the terms physician and surgeon would have been interchangeable in the early middle ages.

34. Annals of Flodoard, s.a. 954, tr. Fanning and Bachrach, 60. "Elephantiasis": Timothy Miller and John Nesbitt, Walking Corpses: Leprosy in Byzantium and the Medieval West (Ithaca and London: Cornell University Press, 2014), 8-9.

35. See Patricia Skinner, "A cure for a sinner: sickness and healthcare in medieval southern Italy," in The Community, the Family and the Saint: Patterns of Power in Early Medieval Europe, ed. J. Hill and M. Swann (Leeds/Turnhout: Brepols, 1998), 297-309, for a specific representation of competition between doctors and the local saints in southern Italy.

36. See above, Chap. 3 and below, Appendix 2 .

37. Leges Visigothorum, Book XI, Title 1, ed. K. Zeumer MGH LL nat. Germ., I: (Hannover and Leipzig: Hahn, 1902), 400-403.

38. Ibid., Book VI, Title IV.1, 262-3.

39. The Theodosian Code and Novels, and the Sirmondian Constitutions, ed. and tr. C. Pharr (New Jersey: The Lawbook Exchange, 2001), Book XIII.

40. MGH LL IV: Leges Langobardorum, Rothari 128 and Liutprand 68, ed. F. Bluhme (Hannover: Hahn, 1868), 30 and 249.

41. Pilsworth, Healthcare, 177-215, collects the evidence for northern Italian medical practitioners termed medici in the early middle ages.

42. MGH LL. nat. Germ. V.1, ed. K. Lehman (Hannover: Hahn, 1966), 8.

43. I have used 'he' and 'him' here and throughout the translations: see above, Chap. 5 , for a discussion of the gendering of language in the lawcodes.

44. The translation of pinna as 'quill' conveys the sense of a fine surgical tool, and is mirrored in the brand-name of modern 'Feather' micro-scalpels: http://www.pfmmedical.com/en/productcatalogue/featherR_micro_scalpels/index.html, [Accessed 11 April 2015]. Pilsworth, Healthcare, 109-110, discusses this passage and its translation.

45. MGH LL. nat. Germ. V.1, ed. K. Lehman (Hannover: Hahn, 1966), 116-117. I have benefited from the comments of Wendy Turner on my understanding of brains 'coming out of the wound': 
this is more likely to mean a swelling, due to injury or rupture of the dura mater, rather than literally a spilling of cerebral matter.

46. Lex Frisionum, ed. K. de Richthofen, in MGH LL, III, ed. G. Pertz (Hannover: Hahn, 1863), 631-700.

47. Lex Baiwariorum, ed. E. Liber, V.3, MGH Leg. nat. Germ. V.2: (Hannover: Hahn, 1926), 339.

48. Welsh law also notes blood dripping to the ground, especially the 'complete blood' from a head wound: The Laws of Hywel Dda (The Book of Blegywryd), tr. M. Richards (Liverpool: Liverpool University Press, 1954), 109.

49. The Laws of Hywel Dda: Law Texts from Medieval Wales, I.3, ed. and tr. Dafydd Jenkins (Llandysul: Gomer Press, 1986), 24-26. And see John Cule, "The court mediciner and medicine in the laws of Wales," Journal of the History of Medicine and Allied Sciences, 21 (1966): 213-266.

50. See also Geoffrey Hodgson, "Dermatology and history in Wales (Cymru)," British Journal of Dermatology, 90 (1974): 699-712.

51. Laws of Hywel Dda, III.8, tr. Jenkins, 196-198.

52. T. G. Watkin, The Legal History of Wales (Cardiff: University of Wales Press, 2007), 46-7.

53. Einhard, letter to Lupus, 836, ed. E. Dümmler, $M G H$ Epistolae Merovingici et Karolingici Aevi, IV (Berlin: Weidmann, 1925), 10 .

54. The Letters of Gerbert with his Papal Privileges as Sylvester II, Letter 1, tr. Harriet Pratt Lattin (New York: Columbia University Press, 1961), 35 .

55. Letters of Gerbert, letters 39 (76-78) and 74 (113).

56. E.g. we know he was interested in the Ophthalmicus of Demosthenes: Letters of Gerbert, letter 16 (55).

57. E.g. he offers prayers and medical information to Archbishop Egbert in 988: Letters of Gerbert, letter 122 (154); and in letter 178 he specifically states that since his correspondent lacks a physician "and we the materials for healing, we have refrained from describing the remedies which the most skilled physicians judge to be useful for an infected liver."

58. The Letters and Poems of Fulbert of Chartres, ed. and tr. F. Behrends (Oxford: Clarendon Press, 1976), letter 71: Deinde amputationis illius vulnera recentia, ne aliquam aliam passionem generent, penalis cauterio timoris ustulabis... Such metaphors predate the 
medieval period of course: Michel Foucault, The History of Sexuality, III: the Care of the Self (New York: Pantheon, 1986), 55, quotes Seneca's Letters to Lucilius, 64.8, outlining much the same scalpel and soothing procedure.

59. Ilana Krug, "The wounded soldier: honey and late medieval military medicine," in Wounds and Wound Repair, ed. DeVries and Tracy, 194-214, discusses its healing qualities.

60. Nam ut solet in proverbiis dici, parum amicus ab officio discordat medici, sicut enim iste corporis sanat cicatrices, ita ille si bene pult animi curat dolores: MGH Die Briefe in der deutschen Kaiserzeit III: die ältere Wormser Briefsammlung, letter 15, ed. W. Bulst (Weimar: Böhlau, 1949), 31-32.

61. Orderic, II.16, (I, 189) and VIII.26 (IV, 316-7).

62. Orderic, III.ii.69-70 (Ralph) and III.ii.79 (Surdus), (II, 74-77 and $88-9$ respectively).

63. Vita S. Udalrici Prioris Cellensis, in MGH SS, XII, ed. G. H. Pertz (Hannover: Hahn, 1856), 258.

64. The Surgery of Theoderic, c. AD 1267, II.6, tr. E. Campbell and J. Cotton (New York: Appleton-Century-Crofts, 1955), 122. He was pessimistic, however, about the patient's chances of survival if the brain had also suffered injury: ibid., II.3, 110.

65. The Assizes of the Lusignan Kingdom of Cyprus, Codex I, clause 225, tr. Nicholas Coureas (Nicosia: Cyprus Research Centre, 2002), 181.

66. M. Rubini and P. Zaio, "Warriors from the East: skeletal evidence of warfare from a Lombard-Avar cemetery in Central Italy (Campochiaro, Molise, 6th-8th century AD)," Journal of Archaeological Science, 38 (2011): 1551-1559.

67. Stuart Mays, "A possible case of surgical treatment of cranial blunt force injury from medieval England," International Journal of Osteoarchaeology, 16 (2006): 95-103: the skull surrounding the injury hole had clearly been scraped to permit lifting of the damaged bone.

68. S. J. Parker, "Skulls, symbols and surgery: a review of the evidence for trepanation in Anglo-Saxon England and a consideration of the motives behind the practice," in Superstition and Popular Magic in Anglo-Saxon England, ed. D. Scragg (Manchester: Manchester Centre for Anglo-Saxon Studies, 1989), 73-84. 
69. Piers Mitchell, Medicine in the Crusades: Warfare, Wounds and the Medieval Surgeon (Cambridge: Cambridge University Press, 2004), 112.

70. Klaeber's Beowulf, 4th Edition, ed. R. D. Fulk, Robert E. Bjork and John D. Niles (Toronto: Toronto University Press, 2008), lines 2973-6. The date of the poem is still, clearly, a controversial issue: The Dating of Beowulf: a Reassessment, ed. Leonard Neidorf (Woodbridge: Boydell, 2014).

71. Bernard S. Bachrach, Early Carolingian Warfare: Prelude to Empire (Philadephia: University of Pennsylvania Press, 2001), 89.

72. Quote from E. T. Brødholt and P. Holck, "Skeletal trauma in the burials from the royal church of St Mary in medieval Oslo," International Journal of Osteoarchaeology, 22.2 (2012): 213; vulnerability: Piers Mitchell et al., "Weapon injuries in the twelfth century crusader garrison of Vadum Iacob castle, Galilee," International Journal of Osteoarchaeology, 16.2 (2006): 153.

73. Influential in setting the agenda for recognizing peri-mortal injury (i.e. injuries likely to have caused death within a few days) was S. J. Wenham, "Anatomical interpretations of Anglo-Saxon weapon injuries," in Weapons and Warfare in Anglo-Saxon England, ed. S. Chadwick Hawkes (Oxford: Oxford University Committee for Archaeology, 1989), 123-139. See e.g. P. Patrick, "Approaches to violent death: a case study from early medieval Cambridge," International Journal of Osteoarchaeology, 16.4 (2006): 347-354, who comments that the individual under scrutiny, who had suffered three weapons injuries from sword blows to the cranium, did not long survive the attack. Contrast, however, the cases from early medieval Maastricht in the Netherlands, discussed by Raphael Panhuysen, "Het scherp van de snede: sporen van geweld in vroegsmiddeleuws Maastricht," Archeologie in Limburg, 92 (2002): 2-7, where two cases of blade injuries to the skull showed signs of healing.

74. The ninth-century Byzantine chronicler Theophanes, however, highlights the spear injury picked up by Emperor Heraclius in a battle against the Persians in AM6118 (625/6 CE): The Chronicle of Theophanes Confessor: Byzantine and Near Eastern History, AD284-813, ed. and tr. C. Mango and R. Scott with the assistance of R. Greatrex (Oxford: Clarendon Press, 1997), 449.

75. Orderic, X.7. 
76. In a moralizing tale of an impious man named Constantine who threw a stone at an icon of the Virgin, Theophanes reports that he was killed at the siege of Nicaea in $725 / 6$ by a stone which broke his head and face: The Chronicle of Theophanes, AM6218, 559-60.

77. Poison: Lex Baiwariorum, IV.21. But the later development of streamlined mail-piercing arrowheads, ironically, may have made them easier to remove, even by the victim himself: Mitchell et al., "Weapon injuries," 152.

78. Richard: above, Chap. 4; Orderic, VII.10 (48-9).

79. Gerald of Wales, The Journey through Wales, II.7, tr. L. Thorpe (London: Penguin, 1978), 188.

80. A. Fornaciari and Valentina Giuffra, "Surgery in the early middle ages: evidence of cauterisation from Pisa," Surgery, 15l (2012), 351-2. I thank Monica Green for pointing out the article's deficiency in terms of textual expertise.

81. Miller, Eye for an Eye, 29.

82. Alexiad, IX.10; English translation Anna Komnena, Alexiad, tr. E. R. A. Sewter (London: Penguin, 1969), 290.

83. The Latin term "malagma" clearly deriving from the Greek $\mu \alpha \lambda \alpha \kappa$ ós for "soft."

84. Both William of Canterbury's account (c. 1172) and that of Benedict of Peterborough (c. 1181) are reproduced in English Lawsuits from William I to Richard I volume II: Henry II and Richard I, case 471B, ed. R. C. Van Caenegem (London: Selden Society vol 107, 1991), 507-514.

85. Herbarium Apulei Platonici, c.2.18-19 (ulcers and blisters), XX.8 (ulcer on nose), XXII.3 (women's pimples), in Leechdoms, ed. Cockayne, I, 87, 117, 119. Leechbook I, cc. 8 (facial blotches), 32-33 (pustules, including leprosy) in Leechdoms, ed. Cockayne, II, 53-4, 77-82.

86. De Ornatu Mulierum, c.272, in The Trotula: a Medieval Compendium of Women's Medicine, ed. Monica H. Green (Philadelphia: University of Pennsylvania Press, 2001), 176-177.

87. Ibid., cc. 273 (freckles), 276 and 286 (refining skin), 278, 280, 282-4 (whitening skin), 288 (scabies) and 290 (sunburn), in The Trotula, 176-183.

88. Alexiad, IX.10 (tr. Sewter, 290). 
89. On the broader history of such voyeurism, though regrettably neglecting the medieval period, see Rosemarie Garland-Thomson, "From wonder to error: a genealogy of freak discourse in modernity," in Freakery: Cultural Spectacles of the Extraordinary Body, ed. R. Garland-Thomson (New York: New York University Press, 1996), 1-19. And see note 87.

90. The Life of St Cadog / Vita Sancti Cadoci, c.36, in Vitae Sanctorum Britanniae et Geneaologiae, ed. A. W. Wade-Evans (Cardiff: University of Wales Press, 1944), 24-141. Caroline Walker Bynum, "Wonder," American Historical Review, 102 (1997): 1-17, emphasizes the difference between the wonder felt and expressed by medieval theologians and philosophers - as a first step to knowledge - and the more negative, exploitative gathering and exhibiting of "wonders" by early modern explorers and their patrons. The Cadog story, whilst apparently conforming to her model, nevertheless nuances it by "allowing" the rustic to exploit his misfortune for financial gain.

Open Access This chapter is distributed under the terms of the Creative Commons Attribution 4.0 International License (http://creativecommons.org/licenses/by/4.0/), which permits use, duplication, adaptation, distribution and reproduction in any medium or format, as long as you give appropriate credit to the original author(s) and the source, provide a link to the Creative Commons license and indicate if changes were made.

The images or other third party material in this book are included in the work's Creative Commons license, unless indicated otherwise in the credit line; if such material is not included in the work's Creative Commons license and the respective action is not permitted by statutory regulation, users will need to obtain permission from the license holder to duplicate, adapt or reproduce the material.

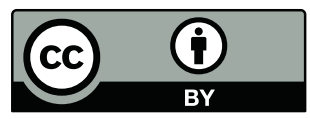

